\title{
The effect of interrupted sexual activity upon the well-rehearsed feeding response'
}

\author{
Paul S. Siegel, UNIVERITY OF ALABAMA \\ Donald E. Jackson, MARY WASHINGTON COLLEGE
}

\begin{abstract}
Adult male albino rats were given preliminary opportunity to engage in sexual interaction with the female and then trained to eat daily during a fixed two-hour interval. On test evenings, just prior to the regularly scheduled feeding period, each $\mathrm{S}$ was given interrupted sexual experience with a receptive female. A reliable diminution in subsequent food intake was observed. This finding was interpreted as possessing relevance to Cofer \& Appley's invigoration hypothesis.

Problem
\end{abstract}

Cofer \& Appley (1964) have proposed two motivational mechanisms which they feel to be sufficient to encompass a broad variety of experimentally established facts: AIM and SIM. AIM, the anticipatory-invigoration mechanism, is represented as a state of augmented vigor arising out of an expectancy established through experience and triggered by associated cues. Fully recognized by the authors, it bears a strong logical resemblance to certain conceptual devices developed by earlier motivational theorists; notably, those of neoHullian persuasion. Kinship with Spence's incentivemotivation construct (1956) is particularly close. SIM, the sensitization-invigoration mechanism, like AIM, serves to invigorate (to Cofer and Appley, motivation equals invigoration), but is held to function in the absence of experience or the opportunity to learn. It is essentially a state of physiological "readiness" set into action by a stimulus spectrum to which the organism is selectively sensitized. Beach's analysis of sex (1956) is the acknowledged model.

Both AIM and SIM are strictly arousal mechanisms and do not serve, in any direct sense, to "steer" the organism. Behavioral direction is lent by interaction with, or the activation of, prevailing S-R associations. Analogy with the familiar Hullian formula, $\mathrm{S}_{\mathrm{R}}=\mathrm{S}_{\mathrm{H}}$ $\mathrm{xD}$, is not a strained one. Quite probably it is this nondifferentiated or scalar property of arousal that has led Cofer and Appley to formulate the issue to which the present experiment is addressed:

"....little attention has been devoted to the question whether the arousal can energize responses other than those specific to the stimuli to which the animal has been sensitized. Can, for example, sexual or maternal arousal energize responses learned and reinforced under food deprivation ?' (Cofer \& Appley, 1964 , p. 828)

\section{Method}

Eighteen mature male albino rats of the Sherman strain were utilized as Ss. At the age of 128 to 138 days, each $\mathrm{S}$ was housed with a single female. At this time (and thereafter), social cues were controlled by liberal spacing and through the placement of opaque screens between cages. The diet (Purina Lab Chow) was presented in dry ground form in a special food cup designed to catch spillage. Water was available at all time. Each "couple" was permitted to feed ad libitum from the cup for three days. A controlled feeding schedule was then instituted. For 13 days, each pair fed during the twohour daily period 6 to $8 \mathrm{P}$. M. It was assumed that, during this stage, the male $\mathrm{S}$ would take on the sexual sophistication necessary to insure a ready mating response in the final phase of the experiment. On the 17 th day, the females were removed; the males continuing on the daily feeding regimen for 18 additional days.

During the subsequent five-day period, each $\mathrm{S}$ was placed, for 3 to $5 \mathrm{~min}$. daily, in an empty top-less enclosure formed from heavy cardboard walls, 12 in in height, presenting a masonite floor area of about $4 \mathrm{sq}$ ft. Experimental tests were carried out in this environment in a common procedure on the four succeeding evenings. Nine pairs of Ss, matched closely on the basis of the two-hour food-intake record yielded during the last training day, were designated. One of each pair was randomly selected as an experimental $\mathrm{S}$; the other served as a control. Just prior to the customary feeding period, the experimental $\mathrm{S}$ was placed alone in the enclosure for $2 \mathrm{~min}$. and then two sexually receptive females introduced. Upon the occurrence of the first mounting reaction, the $\mathrm{S}$ was immediately removed and placed in the home cage together with the familiar food cup. Animals failing to mount were removed to the home cage at the end of $5 \mathrm{~min}$. The matching control was placed alone in the enclosure for the same time interval and, again, just prior to the daily feeding period. In this alternating order (E, C, E, C, etc.), four pairs of matched Ss were treated on the first experimental evening; the remaining five pairs on the succeeding evening. At the end of half-an-hour, the cups were removed, weighed and returned. They were reweighed at the end of two hours. On the third experimental evening, conditions were reversed for the original eight animals; $\mathrm{E}$ animals became $\mathrm{C}$ animals, $\mathrm{C}$ animals became $\mathrm{E}$ animals. The other 10 Ss experienced reversed conditions on the fourth and final evening.

During exposure to the females, with one exception, the $18 \mathrm{Ss}$ proved to be sexually active. Following the preliminary stages of anogenital investigation, pursuit of the female in the "courting run," tentative mounting, 
Table 1. Food Intake Immediately Following Interrupted Sexual Activity

\begin{tabular}{|c|c|c|c|c|c|c|c|c|}
\hline & \multicolumn{4}{|c|}{$\begin{array}{l}\text { Matched Pairs } \\
\text { Test Days } 1 \text { and } 2 \\
\qquad N=9\end{array}$} & \multicolumn{4}{|c|}{$\begin{array}{c}\text { Each } \mathrm{S} \text { as Own Control } \\
\text { Test Days } 1 \text { through } 4 \\
\mathrm{~N}=18\end{array}$} \\
\hline & \multicolumn{2}{|c|}{$\begin{array}{l}\text { Following } \\
\text { Experimental } \\
\text { Treatment }\end{array}$} & \multicolumn{2}{|c|}{$\begin{array}{l}\text { Following } \\
\text { Control } \\
\text { Treatment }\end{array}$} & \multicolumn{2}{|c|}{$\begin{array}{l}\text { Following } \\
\text { Experimental } \\
\text { Treatment }\end{array}$} & \multicolumn{2}{|c|}{$\begin{array}{l}\text { Following } \\
\text { Control } \\
\text { Treatment }\end{array}$} \\
\hline & $\frac{1}{2} \mathrm{Hr} 。$ & $2 \mathrm{Hr}$ 。 & $\frac{1}{2} \mathrm{Hr}$. & $2 \mathrm{Hr}$ 。 & $\frac{1}{2} \mathrm{Hr}$. & $2 \mathrm{Hr}$ 。 & $\frac{1}{2} \mathrm{Hr}$ & $2 \mathrm{Hr}$ \\
\hline Mean & 7.2 & 17.8 & 7.3 & 19.1 & 7.2 & 16.1 & 7.5 & 19.3 \\
\hline S.D。 & 1.77 & 2.97 & 1.27 & 2.25 & 1.54 & 2.96 & 1.56 & 2.57 \\
\hline$t$ & & & 0.01 & 2.77 & & & 1.17 & 4.08 \\
\hline$P$ & & & $>.50$ & $<.02$ & & & $>.20$ & $<.001$ \\
\hline
\end{tabular}

etc., 12 yielded the single copulatory act that was permitted. Five engaged fully in the preliminary activities but failed to mount. Only one displayed sexual inertia and this was not total: he engaged in some examination of the females. It is judged that with the possible single exception noted, the "sexual arousal mechanism" (Beach, 1956) was activated in all Ss.

\section{Results and Diseussion}

Our results are summarized in Table 1. Intakes for the first half-hour and the full two hours are presented separately for the matched pairs of test days 1 and 2 and for all Ss with each serving as his own control (test days 1-4). Summaries of $t$ tests for correlated groups, together with two-tailed $\mathrm{p}$ values, are also found there.

The results reported for the matched pairs, based upon observations made during test days 1 and 2, may be viewed as purer in the sense that no $S$ at that time possessed a history of experimental treatment. With $\mathrm{S}$ serving as his own control (reversal of conditions on days 3 and 4), all Ss, of course, possess a history of the single earlier test experience. Both analyses point to the same conclusion: food intake following the experimental treatment is less than that following control treatment. During the first half-hour, the two begin to separate but not reliably. For the full two-hour interval, the difference is statistically significant. Intake following control treatment is entirely typical of normal or daily baseline intake. The effect of the arousal operation, then, must be taken as inhibitory or depressing.

Within the methodology observed in the present study, a finding of no difference would resist theoretical interpretation. Control intake could well be maximal, imposing a ceiling that, in effect, would render facilitation an impossible outcome. However, this was not the case. Rather, a reliable diminution accompanied the arousal operation. And, in its general form, the question formulated by Cofer and Appley must be answered in the negative. Arousal does not necessarily transfer across situations or "unrelated" response systems. It is, of course, quite possible that other particular instances will differ in outcome. The task, then, becomes that of discovering the conditions under which the effect is or is not a positive one. In the present study, the criterion response (eating) qualifies as consummatory in character. Responses of a more nearly intrumental nature may show facilitation. Final solution will, quite probably, be even more particularized in form.

Plausible account of the present finding of inhibition is to be sought in the likely antagonism of aroused sexual responses (possible autonomic in origin) to eating. Further, the interruption of an ongoing sexual sequence would be viewed by some theorists as frustrating; a circumstance that is sometimes viewed as nonselectively energizing but, with equal frequency, is held likely to arouse disruptive emotional responses.

\section{References}

$\mathrm{BEACH}$, F. A. Characteristics of masculine "sex drive"'. In M. R. Jones (Ed.), Nebra ska Symposium on Motivation. Lincoln: Univ. Nebr. Press, 1956.

COFER, C. N., \& APPLEY, M. H. Motivation: Theory and research. New York: Wiley, 1964. SPENCE, K. W. Behavior theory and conditioning. New Haven: Yale Univ. Press, 1956.

\section{Note}

1. This research was supported in full by the Research Committee of the University of Alabama. 